\title{
Izmeklēšanas noslēpums procesā par noziedzīgi iegūtu mantu
}

\author{
Dr. iur. Sandra Kaija \\ Rīgas Stradiṇa universitāte, Juridiskā fakultāte, \\ Tiesību zinātñu katedra, Latvija \\ sandra.kaija@rsu.lv
}

\section{Kopsavilkums}

Rakstā tiek analizēta izmeklēšanas noslēpuma pamatotība procesā par noziedzīgi iegūtu mantu. Kriminālprocesa likumā nav paredzēts kategorisks aizliegums iepazīstināt personu ar procesa par noziedzīgi iegūtu mantu materiāliem. Tomēr procesā par noziedzīgi iegūtu mantu izmeklēšanas noslēpuma saglabāšana un ievērošana ir nepieciešama, lai nodrošinātu pamata kriminālprocesa norisi, kas lautu sasniegt Kriminālprocesa likuma mērkị, t. i., noteikt tādu kriminālprocesa kārtību, kas nodrošina efektīvu Krimināllikuma normu piemērošanu un krimināltiesisko attiecību taisnīgu noregulējumu bez neattaisnotas iejaukšanās personas dzìvē. Skatot šo jautājumu, jāvērtē, vai labums, ko iegūst sabiedrība, ir lielāks par nodarīto zaudējumu personas tiesībām un likumiskajām interesēm. Kritēriju noteikšanā, lemjot jautājumu par iepazǐ̌̌anos ar lietas materiāliem, jābūt vienveidībai.

Atslēgvārdi: izmeklēšanas noslēpums, noziedzīgi iegūta manta, process.

\section{levads}

Raksts sagatavots, pamatojoties uz Satversmes tiesai sniegto viedokli lietā Nr. 2016-13-01 par Kriminālprocesa likuma 629. panta piektās daḷas atbilstību Latvijas Republikas Satversmes 92. panta pirmajam teikumam (autore lietas izskatǐšanā bija uzaicināta kā pieaicinātā persona). Satversmes tiesas spriedums tika pieņemts 2017. gada 23. maijā [14]. Jautājuma aktualitāti pamato arī tas, ka Satversmes tiesā ir saṇemts vēl viens pieteikums par Kriminālprocesa likuma 629. panta piektās daḷas atbilstību Latvijas Republikas Satversmes 92. panta pirmajam teikumam un Kriminālprocesa likuma 631. panta trešās daļas otrā teikuma atbilstību Satversmes 91. panta pirmajam teikumam, par kuru 2017. gada 10. aprīlī pien,emts lēmums par lietas ierosināšanu [13]. 
Raksta mērḳis ir izpētīt izmeklēšanas noslēpuma pamatotìbu procesā par noziedzīgi iegūtu mantu, konstatēt problēmjautājumus un sniegt iespējamos risinājumus.

Rakstā izmantotas šādas tiesību normu interpretācijas metodes: sistēmiskā interpretācijas metode, lai noskaidrotu tiesību normas jēgu saistībā ar citām tiesību normām, un teleologiskā interpretācijas metode, lai noskaidrotu tiesību normas jēgu, pamatojoties uz lietderīgu un taisnīgu mērḳi, kas ar attiecīgo tiesību normu jāsasniedz.

\section{Svarīgākās atziṇas teorijā un praksē}

Satversmes tiesā tika apstrīdētas normas par Kriminālprocesa likuma (turpmāk - KPL) [5] 629. panta piektās daḷas atbilstību Latvijas Republikas Satversmes (turpmāk - Satversme) 92. panta pirmajam teikumam [6]. Apstrīdētajā normā noteikts, ka procesa par noziedzīgi iegūtu mantu lietas materiāli ir izmeklēšanas noslēpums, un ar tiem drīkst iepazîties procesa virzitājs, prokurors un tiesa, kas izskata šo lietu. Kriminālprocesa likuma 628. pantā minētās personas ar lietas materiāliem var iepazīties ar procesa virzītāja atḷauju un viņa noteiktajā apjomā.

Konstitucionālās sūdzības iesniedzēja uzskatiija, ka apstrīdētā norma neatbilst Latvijas Republikas Satversmes 92. panta pirmajam teikumam un tādējādi nenodrošina procesuālās vienlīdzības (līdzvērtības) principu, un pārkāpj tiesības uz taisnīgu tiesu. Latvijas Republikas Satversmes 92. panta pirmajā teikumā noteikts: "Ikviens var aizstāvēt savas tiesības un likumiskās intereses taisnīgā tiesā" [6]. Šãda garantija atbilst svarīgākajos starptautiskajos tiesību aktos, piemēram, ANO Vispārējo Cilvēktiesību deklarācijas 10. pantā [2], Eiropas Cilvēktiesību un pamatbrīvību aizsardzības konvencijas 6. pantā [3], ANO Starptautiskā pakta par pilsoṇu un politiskajām tiesībām 14. pantā [1] deklarētajām tiesībām.

Eiropas Cilvēktiesību un pamatbrīvību aizsardzības konvencijas 6. panta pirmajā dạ̦ā noteikts, ka, nosakot civilo tiesību un pienākumu vai izvirzìtās apsūdzības krimināllietā pamatotību, ikvienam ir tiesības uz taisnīgu un atklātu lietas savlaicīgu izskatīšanu neatkarīgā un objektīvā, ar likumu noteiktā tiesā. Tiesas spriedumu jādara publiski zināmu, taču preses un publikas klātbūtne procesā var tikt pilnībā vai dal̦ēji aizliegta tikumisku apsvērumu, sabiedriskās kārtības vai valsts drošības interesēs tādā demokrātiskā sabiedrībā, kurā to prasa nepilngadīgo intereses vai procesa dalībnieku privātās dzīves aizsardzība, vai arī tajā apmērā, kuru tiesa uzskata par absolūti nepieciešamu ipašos apstākḷos, kad atklātība apdraudētu taisnīguma intereses.

Eiropas Cilvēktiesību un pamatbrīvību aizsardzības konvencijā paredzētas divas galvenās taisnīgas lietas izskatī̌sanas garantiju grupas:

1) organiskās garantijas vērstas uz to, lai šāda lietas izskatî̌ana būtu iespējama, tādējādi valsts iestādēm tiek uzlikta virkne pienākumu (izveidot likumīgu tiesu, saglabāt neitralitāti, ievērot lietas izskatī̌̌anas publiskumu u. tml.);

2) funkcionālās garantijas vērstas uz vienlīdzīguma nodrošināšanu visās procesa stadijās [16].

Secināms, ka konvencijas 6. panta prasība par procesuālās līdzvērtības nodrošināšanu ir pieskaitāma funkcionālajām garantijām. 
Kriminālprocesa kvalitāte mūsdienu apstākḷos diezgan bieži ir atkarīga no tiesības uz taisnīgu un atklātu lietas savlaicīgas izskatī̌sanas nodrošināšanu neatkarīgā un objektīvā, ar likumu noteiktā tiesā. Starp Latvijas Republikas Satversmes 8. nodaḷā noteiktajām cilvēka pamattiesībām ir valsts atzìtas un aizsargātas cilvēka pamattiesības saskaṇā ar Satversmi, likumiem un Latvijai saistošiem starptautiskajiem līgumiem. Satversme arī garantē, ka ikviens var aizstāvēt savas tiesības un likumiskās intereses taisnīgā tiesā.

Kriminālprocesa likuma 17. pantā noteikts, ka kriminālprocesā iesaistītajām personām ir pilnvaras (tiesỉbas un pienākumi), kas viṇām nodrošina normatīvajos aktos noteikto uzdevumu un garantēto tiesību lïdzvērtīgu īstenošanu.

Procesuālo pilnvaru līdzvērtības princips darbojas visa kriminālprocesa laikā. Tomēr procesuālo pilnvaru līdzvērtība nenozīmē, ka visu kriminālprocesā iesaistīto personu tiesībām un pienākumiem jābūt absolūti vienādiem.

Jāuzsver, ka šis princips ir reglamentēts diezgan vispārīgi un "līdzvērtīga îstenošana", protams, ir vērtējuma jēdziens, kas piepildāms katrā konkrētā gadījumā. Tāpat jāatzīmē, ka šis princips nav identisks vienlīdzīguma principam. Vienlīdzīguma princips paredz vienādu attieksmi pret vienādā statusā un vienādos apstākḷos esošām personām, savukārt procesuālo pilnvaru līdzvērtīguma princips var būt attiecināms uz dažādiem procesa dalībniekiem, kuriem kādā konkrētā brīdī procesā ir uzlikti vienādi pienākumi, piešķirtas vienādas tiesības $u$. tml. Šis princips nozīmē, ka procesa dalībniekiem jānodrošina līdzvērtīgas (bet ne obligāti vienādas) iespējas tās īstenot $u$. tml. Piemērojot praksē dažādas kriminālprocesa normas, tieši prakses darbiniekiem jābūt tiem, kas rūpīgi ievēro šo vienlīdzīguma idejas îstenošanu [19, 64].

Taisnīgas tiesas jēdziens ietver arī pušu līdzvērtīgu iespēju principu. Tas paredz, pirmkārt, visām procesā iesaistītajām pusēm iespēju izklāstìt lietas apstākḷus un, otrkārt, liedz kādai no pusēm pieškirt būtiskas priekšrocības salīdzinājumā ar oponentu [18, 6]. Tomēr jāṇem vērā, ka tas nenozīmē, ka atsevišḳos gadījumos (vai atsevišḳu kategoriju lietās) šādas priekšrocības nevarētu būt pamatotas [17, 135].

Procesuālās līdztiesības princips (equality of arms) ir būtisks tiesību uz taisnīgu tiesu elements un vienlaikus arī tiesiskās vienlīdzības principa īpašā izpausme, kas attiecināma uz visu kategoriju tiesai pakḷautajām lietām. Tas noteic, ka lietas izskatīšanas procesā procesa dalībnieku tiesībām jābūt taisnīgi līdzsvarotām (fair balance), proti, katram ir jābūt nodrošinātam ar adekvātām iespējām izmantot procesuālos līdzekḷus, neesot nepamatoti nostādītam nelabvēlīgākā stāvoklī kā citi procesa dalībnieki. No procesuālās līdztiesības principa tādējādi izriet valsts pienākums izveidot tādu lietu izskatî̌̌nas procesuāltiesisko regulējumu, kas to nodrošina [17, 134-135].

Risinot jautājumu par tiesībām iepazīties ar procesa par noziedzīgi iegūtu mantu lietas materiāliem, svarīgi ir novērtēt, vai ierobežojums atbilst visiem pamattiesību ierobežojuma konstitucionalitātes testā ietvertajiem kritērijiem:

1) pamattiesību ierobežojumam ar likumu;

2) leǵitìmajam mērḳim;

3) samērīgumam $[15,10]$. 
Pamattiesību ierobežojums ar likumu. Izvērtējot pamattiesību ierobežojuma atbilstību Satversmei, vispirms jāpārbauda:

1) vai ierobežojums noteikts ar pienācīgā kārtā pieṇemtu likumu, t. i., vai likums ir pieñemts, ievērojot normatīvajos aktos paredzēto kārtību;

2) vai likums ir izsludināts un publiski pieejams atbilstoši normatīvo aktu prasībām;

3) vai likums ir pietiekami skaidri formulēts, lai persona varētu izprast no tā izrietošo tiesību un pienākumu saturu un paredzēt tā piemērošanas sekas;

4) vai likums nodrošina aizsardzību pret tā patvaḷigu piemērošanu (piemēram, sk. Satversmes tiesas 2009. gada 4. februāra spriedumu lietā Nr. 2008-12-01 Par Komerclikuma 142. panta otrās daḷas un 284. panta otrās dalıas atbilstību Latvijas Republikas Satversmes 1. un 105. pantam 10.1. punktu [15]).

Domājams, pirmie divi punkti šaubas nerada. Kriminālprocesa likuma 629. panta piektajā dạ̦ā paredzētais ierobežojums noteikts ar pienācīgā kārtā pieṇemtu likumu, un likums ir pien,emts, ievērojot normatīvajos aktos paredzēto kārtību, kā arī likums ir izsludināts un publiski pieejams atbilstoši normatīvo aktu prasībām.

Lietā Medvedyev un citi pret Franciju Eiropas Cilvēktiesību tiesa norāda, ja runa ir par to, vai ir ievērota prasība "likumā noteiktā kārtībā", tad Konvencija būtībā atsaucas uz nacionālo likumu un nosaka pienākumu ievērot nacionālā likuma materiālās un procesuālās normas [11].

Trešā punkta prasība, lai likums nodrošina aizsardzību pret tā patvalīgu piemērošanu, var tikt isstenota, n̦emot vērā piennemtā lēmuma pārsūdzību. Satversmes tiesa akcentēja, ka procesa virzìtājs, kas vienlaikus ir viena no procesa par noziedzīgi iegūtu mantu pusēm, kas turklāt joprojām turpina izmeklēt noziedzīgo nodarỉjumu, pien,emot lēmumu par iepazišanos ar noziedzīgi iegūtas mantas lietas materiāliem, rada pamatotas šaubas par šā lēmuma objektivitāti un neatkarību, ja saskañā ar taisnīgas tiesas principu šāds lēmums netiek pārvērtēts tiesā. Tikai procesā, kurā tiek nodrošināts pušu līdzvērtīgu iespēju princips, var nonākt līdz taisnīgam tiesas nolēmumam pēc būtības. Likumdevējam būtu jāparedz kārtība, kas nodrošinātu pušu līdzvērtīgu iespēju principu šajās lietās, paredzot tiesai iespēju pārbaudīt procesa virzītāja lēmuma par personas tiesībām iepazìties ar procesa par noziedzīgi iegūtu mantu lietas materiāliem tiesiskumu un pamatotību, tādējādi nodrošinot personai efektīvu īpašuma tiesību aizsardzību. Tieši tiesa ir tas subjekts, kam, izskatot jautājumu pēc būtỉbas, vienlaikus būtu jāveic ar mantu saistīto personu pamattiesību ievērošanas kontroles funkcija. Turklāt tiesa, izskatot lietu pēc būtības, jebkurā gadỉjumā iepazīstas ar visiem procesa par noziedzīgi iegūtu mantu lietas materiāliem [14]. Tādēḷ KPL jāveic grozījumi, ìstenojot Satversmes tiesas spriedumā noteikto. Jāṇem vērā arī Eiropas Parlamenta un Padomes Direktīvā 2014/42/ES par nozieguma rīku un noziedzīgi iegūtu līdzekḷu iesaldēšanu un konfiskāciju Eiropas Savienībā norādīto, ka attiecīgajai personai ir efektīva iespēja pārsūdzēt lietas apstākḷus, tostarp konkrētus faktus un pieejamos pierādījumus, kuri ir pamatā tam, lai īpašumu uzskatītu par iegūtu no noziedzīgas darbības [4]. 
Tomēr var piekrist konstitucionālās sūdzības iesniedzējai, ka normā nav paredzēti kritēriji, pēc kuriem procesa virzìtājam jāvadās, lemjot par aț̣aujas iepazìties ar lietas materiāliem izsniegšanu. Saeima savā atbildē norāda, ka šādā situācijā likumdevējam nav nepieciešams un pat nav iespējams noteikt precīzus un detalizētus kritērijus procesa virzitāja lēmuma pien,emšanai.

Arī Satversmes tiesa savā spriedumā norāda, ka kritēriji, kas procesa virzìtājam jāṇem vērā, lemjot par personas tiesībām iepazìties ar procesa par noziedzīgi iegūtu mantu lietas materiāliem, jau šobrīd pastāv tiesību sistēmā un, sistēmiski interpretējot tiesību normas, ir tieši piemērojami, tāpēc tos atkārtoti ietvert normatīvajā regulējumā nav nepieciešams [14].

Neapšaubāmi, var piekrist Satversmes tiesai. Tomēr jāatzīst, ka KPL nav ievērota vienveidība, jo dažos gadījumos šādi kritēriji likumā ir noteikti, piemēram, KPL 60. ${ }^{2}$ panta trešās daḷas 1. punktā noteikts, ka viena no personas, kurai ir tiesības uz aizstāvību, pamattiesībām kriminālprocesā ir iepazīties ar tiem lietas materiāliem, ar kuriem pamatots ierosinājums piemērot ar brīiības atṇemšanu saistītu drošības līdzekli, ciktāl šāda piekḷve neapdraud citu personu pamattiesības, sabiedrības intereses un netraucē kriminālprocesa mērksa sasniegšanu [5]; KPL 231. pants, kurā reglamentēta iepazīšanās kārtība ar materiāliem (pārskatiem par speciālajām izmeklēšanas darbībām, kā arī ar tehniskajiem līdzekḷiem fiksētiem materiāliem, par kuriem procesa virzītājs atzinis, ka tiem nav pierādījumu nozīmes kriminālprocesā), kas nav pievienoti krimināllietai. Šì panta trešajā daḷā noteikts, ka izmeklēšanas tiesnesis izvērtē pieteikumu, ṇemot vērā materiālu iespējamo nozīmi kriminālprocesā un pieḷautos cilvēka tiesību ierobežojumus, un var liegt iespēju iepazìties ar nepievienotajiem materiāliem, ja tas var bütiski apdraudēt kādas kriminālprocesā iesaistītās personas dzīvību, veselību vai ar likumu aizsargātās intereses vai ja tas aizskar tikai trešās personas privātās dzìves noslēpumu [5] (autores izcēlumi). Skaidra un precīza tiesiskā regulējuma, konkrētu kritēriju neesamība procesā par noziedzīgi iegūtu mantu var izraisīt personu tiesību nepamatotus pārkāpumus normas piemērošanas praksē, liedzot personām iespēju uz pilnvērtīgu tiesisko aizsardzību. Turklāt process par noziedzīgi iegūtu mantu visbiežāk (faktiski - vienmēr) tiks pabeigts ātrāk nekā pamata kriminālprocess, tādējādi persona, kuras intereses attiecīgais process skar, var vispār netikt iepazīstināta ar materiāliem, kas ir pamatā mantas atzišanai par noziedzīgi iegūtu. Tātad izmeklēšanas noslēpuma sargāšana šajā gadījumā ir izvērtējama ar vislielāko rūpību.

Leǵitīmais mērḳis. Satversmes tiesa ir norādījusi, ka ikviena personas pamattiesību ierobežojuma pamatā jābūt apstākḷiem un argumentiem, kādēḷ tas vajadzịgs. Tātad ierobežojumam jābūt noteiktam svarīgu interešu - leg̣itīmo mērḳu - labad. Pamattiesību ierobežojumus iespējams attaisnot ar dažādiem apstākḷiem. Likumdevējam parasti ir konkrēti mērḳi, kurus tas vēlas sasniegt ar tiesību normā noteikto pamattiesību ierobežojumu. Lai kādi būtu likumdevēja nolūki, pamattiesību ierobežojumu tas var noteikt tikai gadijjumā, ja ar to tiek sasniegts kāds no Satversmes 116. pantā minētajiem 
legitīmajiem mērḳiem. Proti, pamattiesības var ierobežot, lai aizsargātu citu cilvēku tiesības, demokrātisko valsts iekārtu, sabiedrības drošību, labklājību un tikumību. Šīs piecas konstitucionāla ranga vērtības ir tie legitīmie mērḳi, kuru labad var notikt pamattiesību ierobežošana (sk., piemēram, Satversmes tiesas 2009. gada 15. aprị̣̄a spriedumu lietā Nr. 2008-36-01 [15]).

Kriminālprocesam raksturīga un būtiska pazìme ir ziṇu iegūšana par faktiem, kas nepieciešamas taisnīgam krimināltiesisko attiecību noregulējumam, un to fiksēšana krimināllietas materiālos. Process par noziedzīgi iegūtu mantu plašã izpratnē ir kriminālprocesuāla darbība, proti, tāda darbība, kas reglamentēta KPL. Arī Augstākā tiesa norāda, ka to, kāda darbība uzskatāma par kriminālprocesuālu darbību, nosaka pats Kriminālprocesa likums, proti, kriminālprocesuāla darbība ir tāda darbība, kas tiek regulēta Kriminālprocesa likumā [12]. Jebkuras procesuālās darbības veikšanai jābūt pamatotai, vērstai uz konkrētā mērḳa sasniegšanu. Citiem vārdiem sakot, procesuālās darbỉbas pamats ir apstākḷu kopums, kas liecina par to, ka konkrētās procesuālās darbības izdarǐšana ir nepieciešama KPL mērḳa sasniegšanai.

Kriminālprocesā ir vērojama tendence paplašināt kriminālprocesā iesaistīto personu iespējas iepazîties ar krimināllietas materiāliem, lai îstenotu savas tiesības un brīvības. Tã ir ne tikai tradicionālā iepazišanās ar krimināllietas materiāliem, pabeidzot pirmstiesas procesu, bet arī saṇemot dažādu dokumentu kopijas, piemēram, kratīšanas lēmuma un protokola kopijas (KPL 181. un 185. pants); pirms pieņemt lēmumu piemērot par drošỉbas lïdzekli, kurš saistîts ar brīvïbas atṇemšanu, procesa virzitājs izsniedz personai, kurai ir tiesības uz aizstāvību, ierosinājuma kopiju, kurā norādìts konkrētā drošības līdzekḷa izvēles pamatojums ar konkrētiem, uz lietas materiāliem balstītiem apsvērumiem (KPL 246. pants); aizstāvim ir tiesības KPL 83. panta pirmajā daḷā minētajos obligātās aizstāvības gadỉjumos iepazìties ar visiem lietas materiāliem no apsūdzības izsniegšanas brī̌̌a un saṇemt šo materiālu kopijas (KPL 86. pants); protokola kopiju par aresta uzlikšanu mantai izsniedz pret parakstu personai, pie kuras izdarīta mantas aprakste, vai vienam no šīs personas pilngadīgajiem ğimenes locekḷiem, bet, ja to nav klāt, - tās vietējās pašvaldības pārstāvim, kuras administratīvajā teritorijā mantai uzlikts arests (KPL 363. pants).

Taču iepazî̌anās ar krimināllietas materiāliem konkurē ar izmeklěšanas noslēpumu pirmstiesas kriminālprocesā. Visi krimināllietas materiāli nav atzīstami par izmeklēšanas noslēpumu, tomēr kriminālprocesa intereses prasa saglabāt noteiktu pirmstiesas procesā iegūtu ziṇu par faktiem konfidencialitāti.

Kriminālprocesa likumā tiek izmantots jēdziens "izmeklēšanas noslēpums", tas atspoguḷots vairākos KPL pantos:

1) 219. panta (Automatizētās datu apstrādes sistēmā esošo datu kontrole) trešajā daḷā - procesa virzìtājs var aizliegt šai personai citu darbỉbu veikšanu ar kontrolei pakḷautajiem datiem, kā arī brīdina šo personu par izmeklēšanas noslēpuma neizpaušanu; 
2) 234. panta (Krimināllietai nepievienotajos materiālos ietvertās informācijas aizsardzības pasākumi) pirmajā dạ̣ā - speciālās izmeklēšanas darbības veikšanas metodes, paṇēmieni un līdzekḷi, kā arī tās rezultātā iegūtās ziṇas, kurām nav pierādījumu nozīmes kriminālprocesā, kurā šì darbība veikta, vai kuru izmantošana citā kriminālprocesā nav aț̣auta, vai kuras nav nepieciešamas sabiedrības drošības tūlītēja būtiska apdraudējuma novēršanai, ir valsts vai izmeklēšanas noslēpums, un personas par to izpaušanu atbild Krimināllikumā noteiktajā kārtībā;

3) 375. panta (Iepazišanās ar krimināllietas materiāliem) pirmajā dạ̣ā - kriminālprocesa laikā krimināllietā esošie materiāli ir izmeklēšanas noslēpums un ar tiem drīkst iepazìties amatpersonas, kuras veic kriminālprocesu, kā arī personas, kurām minētās amatpersonas attiecīgos materiālus uzrāda šajā likumā paredzētajā kārtībā;

4) 629. panta (Tiesas process par noziedzīgi iegūtu mantu) piektajā daḷā - procesa par noziedzīgi iegūtu mantu lietas materiāli ir izmeklēšanas noslēpums, un ar tiem drīkst iepazîties procesa virzitājs, prokurors un tiesa, kas izskata šo lietu. Šã likuma 628. pantā minētās personas ar lietā esošie materiāliem var iepazīties ar procesa virzītāja aț̣auju un viṇa noteiktajā apjomā.

Process par noziedzīgi iegūtu mantu skatāms kontekstā ar Kriminālprocesa likuma 1. pantā noteikto mērḳi - efektīvu krimināllikuma normu piemērošanu un taisnīgu krimināltiesisko attiecību noregulējumu bez neattaisnotas iejaukšanās personas dzīvē. Tādēl rūpīgi jāizvērtē, vai konkrēts personu ierobežojošs procesuāls pasākums tiešām ir nepieciešams un vai tā piemērošana vispār vai noteiktā pakāpē ir uzskatāma par tiesiski attaisnojamu iejaukšanos personas darbībā. Jāatzīst, ka personu tiesības iepazīties ar procesa par noziedzịgi iegūtu mantu lietas materiāliem nav absolūtas, un tās var tikt ierobežotas ar leǵitīmu mērki neapdraudēt citu personu pamattiesības, sabiedrības intereses un netraucēt kriminālprocesa mērḳa sasniegšanu. Šāds secinājums balstìts uz to, ka zinnas par faktiem, kuras ir procesa virzìtāju rīcībā, objektīvi izraisa to personu interesi, kuras var pretdarboties kriminālprocesa interesēm. (Ar pretdarbošanos jāsaprot ne tikai dažādi noziedzīgā nodarījuma slēpšanas veidi un formas, bet tā jātulko plašāk, ar pretdarbošanos saprotot jebkuru personu apzinātu darbỉbu ar mērḳi kavēt kriminālprocesu un tā mērḳa sasniegšanu.) Krimināllietas materiāli var saturēt informāciju, kas tieši vai netieši saistīta ar dažādu noslēpumu aizsardzību (personas privātās dzīves noslēpumu, valsts noslēpumu, komercnoslēpumu, izmeklēšanas noslēpumu u. c.), un tās neatḷauta izplatišsana var pārkāpt kriminālprocesā iesaistīto un citu personu tiesības. Nepamatota pirmstiesas procesa datu izpaušana var nopietni sarežg̀it arī kriminālprocesa, no kura izdalīti materiāli par noziedzīgi iegūtu mantu, izmeklēšanu, tās dẹl var zaudēt kriminālprocesā iegūtos pierādījumus, radìt apstākḷus pierādījumu iespējamai iznīcināšanai, prettiesiski ietekmēt liecinošās personas, ḷaut personai, kurai ir tiesības uz aizstāvību, izvairīties no pirmstiesas procesa un tiesas, vai citādi pretdarboties kriminālprocesam. 
Lietā Svipsta pret Latviju, lietā Mikselsons pret Latviju, kā arī Garcia Alva vs. Germany, Lietzow vs. Germany $[9,10,7,8]$ u. c. lietās Eiropas Cilvēktiesību tiesa atzinusi krimināllietu efektīvas izmeklēšanas nepieciešamību, kas attaisnotu to, ka daḷa no izmeklēšanas gaitā savāktās informācijas ir konfidenciāla un netiek izpausta, lai apsūdzētie nevarētu mainìt pierādījumus un traucēt likuma piemērošanu.

Eiropas Cilvēktiesību tiesa norāda, ka šo leğitīmo mērḳi tomēr nedrīkst îstenot uz būtiska personas tiesību ierobežojuma rēḳina. Vērtējot šo aspektu, jāmin KPL 628. pants, kurā expressis verbis noteikts procesa virzītāja pienākums izsniegt attiecīgajai personai - aizdomās turētajam vai apsūdzētajam un personai, pie kuras manta tika izṇemta vai tai tika uzlikts arests, ja šādas personas attiecīgajā kriminālprocesā ir, vai arī citai personai, kurai ir tiesības uz konkrēto mantu - lēmuma kopiju par to, ka nolemts uzsākt procesu par noziedzīgi iegūtu mantu.

Lēmumā procesa virzītājam jānorāda:

1) zinas par faktiem, kas pamato mantas saistìbu ar noziedzīgu nodarïjumu vai mantas noziedzīgo izcelsmi, kā arī to, kādi materiāli no izmeklēšanā esošās krimināllietas par noziedzīgu nodarỉjumu tiek izdalīti lietā par noziedzīgi iegūtu mantu;

2) kuras personas ir saistītas ar konkrēto mantu;

3) kādu rīcību ar noziedzīgi iegūtu mantu viņš ierosina (KPL 627. panta otrā daḷa).

Tādējādi likumā paredzētas noteiktu personas tiesības saṇemt informāciju par procesu par noziedzīgi iegūtu mantu noteiktā formā, proti, saṇemt attiecīgā lēmuma kopiju bez ìpaša pieprasijjuma, turklāt tas notiek nekavējoties pēc lēmuma pieņemšanas. Lìdz ar to apstrīdētā norma ḷauj legiitìmo mērḳi ìstenot vienlaikus ar kriminālprocesā aizskartā mantas īpašnieka tiesībām, jo paredz personai tiesības saṇemt procesa virzītāja lēmuma kopiju, tādējādi saṇemot informāciju arī par to, kādi materiāli no izmeklēšanā esošās krimināllietas par noziedzịgu nodarījumu tiek izdalīti lietā par noziedzīgi iegūtu mantu.

Samērīgums. Vērtējot samērīgumu, jānorāda, ka process par noziedzīgi iegūtu mantu tiek uzsākts savlaicīgas atrisināšanas un procesa ekonomijas interesēs, ja tam piekrīt uzraugošais prokurors. Procesa virzītājam ir tiesības pirmstiesas kriminālprocesā izdalìt no krimināllietas materiālus par noziedzīgi iegūtu mantu un uzsākt procesu tikai tajā gadỉjumā, ja pastāv šādi nosacījumi:

1) pierādijumu kopums dod pamatu uzskatit, ka mantai, kura izņemta vai kurai uzlikts arests, ir noziedzīga izcelsme vai saistība ar noziedzīgu nodarījumu;

2) objektīvu iemeslu dēl krimināllietas nodošana tiesai tuvākajā laikā (saprātīgā laika periodā) nav iespējama vai var radīt būtiskus neattaisnotus izdevumus.

Tas nozìmē, ka pamata process ir tikai pirmstiesas procesa stadijā (pirmstiesas izmeklēšanā vai kriminālvajāšanā), līdz ar to apstrīdētajā normā paredzētais ierobežojums tiek vērsts uz noziedzīgo nodarījumu efektīvu izmeklēšanu un citu personu tiesību aizsardzību, ar apstrīdēto normu var sasniegt ierobežojuma leǵitīmo mērḳi. 
Sandra Kaija. Izmeklēšanas noslēpums procesā

par noziedzīgi iegūtu mantu

Turklāt katram no procesiem ir atšksirīgi mērḳi.

Vienā gadījumā kriminālprocesā jānoskaidro:

1) vai ir noticis noziedzịgs nodarijums;

2) persona, kura saucama pie kriminālatbildības;

3) vai ir pamats kriminālprocesa izbeigšanai, pabeigšanai vai virzī̌̌anai uz tiesu (KPL 384. pants).

Tātad kriminālprocesā jāizlemj jautājums par personas vainas konstatāciju noziedzīgā nodarījuma izdarǐšanā.

Savukārt procesā par mantas atzīšanu par noziedzīgi iegūtu tiesas uzdevums nav lemt jautājumu par personas vainu, bet par to, vai manta ir saistīta ar noziedzīgu nodarijumu, vai mantas izcelsme ir noziedzīga u. tml. atbilstoši KPL 630. pantā noteiktajam. Procesā par mantas atzī̌anu par noziedzīgi iegūtu netiek risināts apsūdzības pamatotības jautājums. Turklāt procesa virzìtājs (ja tas ir izmeklētājs - ar prokurora piekrišanu), kurš pieņem lēmumu uzsākt procesu par noziedzịi iegūtu mantu, pats neizlemj jautājumu pēc būtîbas, bet lēmumu un tam pievienotos materiālus nosūta rajona (pilsētas) tiesai. Tiesas sēdē tiek uzklausìts procesa virzītājs, prokurors, pārējās uzaicinātās un ieradušās personas, vinu pārstāvji vai aizstāvji. Tiesas sēdē, nodrošinot procesuālo pilnvaru līdzvērtības principu, tiesas procesā iesaistītajām personām ir vienādas tiesības pieteikt noraidījumus vai lūgumus, iesniegt pierādījumus, iesniegt tiesai rakstveida paskaidrojumus, kā arī piedalīties tiesas procesa gaitā radušos citu jautājumu izskatīšanā.

\section{Secinājumi un priekšlikumi}

1. Kriminālprocesa likuma 629. panta piektā daḷa neparedz kategorisku aizliegumu iepazīstināt personu ar procesa par noziedzịgi iegūtu mantu materiāliem.

2. Izmeklēšanas noslēpuma saglabāšana un ievērošana procesā par noziedzīgi iegūtu mantu ir nepieciešama, lai nodrošinātu pamata kriminālprocesa norisi, kas ḷautu sasniegt KPL mērḳi, t. i., noteikt tādu kriminālprocesa kārtību, kas nodrošina efektīvu Krimināllikuma normu piemērošanu un krimināltiesisko attiecību taisnīgu noregulējumu bez neattaisnotas iejaukšanās personas dzīvē. Skatot šo jautājumu, jāvērtē, vai labums, ko iegūst sabiedrība, ir lielāks par personas tiesībām un likumiskajām interesēm nodarìto zaudējumu.

3. Kritēriju noteikšanā, lemjot jautājumu par iepazī̌sanos ar lietas materiāliem, jābūt vienveidībai. Tās nodrošināšanai saskatāmi divi risinājumi:

1) KPL 629. panta piektā daḷa jāpapildina ar konkrētiem kritērijiem, kas jāṇem vērā, izlemjot jautājumu, l̦aut vai nel̦aut iepazìties ar procesa materiāliem;

2) šādus kritērijus neparedzēt arī citās KPL normās, bet atstāt to tiesību normu interpretācijai, balstoties uz kriminālprocesa pamatprincipiem.

4. N̦emot vērā Satversmes tiesas spriedumu, jāveic grozijumi KPL, ciktāl tiesa nevar pārvērtēt procesa virzītāja lēmuma par personas tiesībām iepazìties ar procesa par noziedzīgi iegūtu mantu lietas materiāliem tiesiskumu un pamatotību. 


\section{Secret of Investigation in Proceedings Regarding Criminally Acquired Property}

\section{Abstract}

The article analyses the issue of investigative secrecy merits in the process of criminally acquired property. The author concludes that the Criminal Procedure Law does not introduce a categorical ban for people to get acquainted with the materials of the process of criminally acquired property. However, investigative secrecy and respect for the process of criminally acquired property is required to ensure the basic criminal conduct that would result in the Criminal Procedure Law objective, namely to determine the order of criminal procedure that ensures the effective application of the norms of the Criminal Law and the fair regulation of criminal legal relations without unjustified intervention in the life of a person. When viewing this issue, it is needed to assess whether the benefit gained by the society is greater than the damage caused to the rights of an individual and legal interests.

The author believes that the setting of the criteria in deciding the question of access to the file must be done in uniformity.

Keywords: secret of investigation, criminally acquired property, proceedings.

\section{Izmantotie avoti un literatūra}

\section{Tiesību akti}

1. ANO Starptautiskais pakts par pilsonu un politiskajām tiesībām. Parakstìts 1966. gada 16. decembrī. Latvijas Vēstnesis. 61(2826), 23.04.2003.

2. ANO Vispārējā cilvēktiesību deklarācija. LU Juridiskās fakultātes Cilvēktiesību institūts. Iegūts no: http://www.humanrights.lv/doc/vispaar/vispcd.htm [sk. 24.05.2017.].

3. Eiropas Cilvēktiesību un pamatbrīvību aizsardzības konvencija. Latvijas Vēstnesis. 143/144, 13.06.1997.

4. Eiropas Parlamenta un Padomes Direktīva 2014/42/ES (2014. gada 3. aprīlis) par nozieguma rīku un noziedzīgi iegūtu līdzekḷu iesaldēšanu un konfiskāciju Eiropas Savienībā. ES Oficiālais Vēstnesis. L 127, 29.04.2014.

5. Kriminālprocesa likums: Latvijas Republikas likums. Latvijas Vēstnesis. 74(3232), 11.05.2005.

6. Latvijas Republikas Satversme: LV likums: pienemta 15.02.1922. Latvijas Vēstnesis. 43, 01.07.1993.

\section{Tiesu prakse}

7. Eiropas Cilvēktiesību tiesas 2001. gada 13. februāra spriedums lietā Garcia Alva vs. Germany, iesniegums Nr. 23541/94.

8. Eiropas Cilvēktiesību tiesas 2001. gada 13. februāra sprieduma lietā Lietzow vs. Germany, iesniegums Nr. 24479/94.

9. Eiropas Cilvēktiesību tiesas 2006. gada 9. marta sprieduma lietā Svipsta vs. Latvia, iesniegums Nr. 66820/01. 
10. Eiropas Cilvēktiesību tiesas 2015. gada 3. novembra spriedums lietā Miḳ̂lsons vs. Latvia, iesniegums Nr. 46413/10.

11. Eiropas Cilvēktiesību tiesas 2010. gada 29. marta Lielās palātas spriedums lietā Medvedyev un citi pret Franciju, iesniegums Nr. 3394/03.

12. Latvijas Republikas Augstākās tiesas Senāta Administratīvo lietu departamenta 2010. gada 21. maija lēmums, lieta Nr. SKA-528/2010.

13. Satversmes tiesas lēmums par lietas ierosināšanu lietā Nr. 2016-13-01, 2017. gada 10. aprīlis. Iegūts no: http://www.satv.tiesa.gov.lv/wp-content/uploads/2017/04/2017-10-01_Lemums_ ierosinasana.pdf [sk. 18.05.2017.].

14. Satversmes tiesas spriedums lietā Nr. 2016-13-01, 2017. gada 23. maijs. Pieṇemts 23.05.2017. Latvijas Vēstnesis. 102(5929), 25.05.2017.

\section{Literatūra}

15. Balodis, K. Pamattiesību ierobežojuma konstitucionalitātes izvērtēšana Satversmes tiesā. Jurista Vārds. 21(924), 24.05.2016.

16. Kommentarii k Konvencii o zashchite prav cheloveka i osnovnykh svobod i praktike ee primeneniia. (Комментарий к Конвенции о защите прав человека и основных свобод и практике ее применения.) Iegūts no: http://www.hri.ru/docs/?content=doc\&id=371 [sk. 24.05.2017.].

17. Latvijas Republikas Satversmes komentāri. VIII nodal̦a. Cilvēka pamattiesības. Autoru kolektīvs prof. R. Baloža zinātniskā vadībā. Rīga: Latvijas Vēstnesis, 2011.

18. Law and Practice of the European Convention on Human Rights and the European Social Charter. Council of Europe, 1996.

19. Meikališa, Ā., Strada-Rozenberga, K. Kriminālprocesa veidi, uzbūves raksturojums un pamatprincipi. No: Meikališa, Ā., Strada-Rozenberga, K. Kriminālprocess. Raksti 2005-2010. Rīga: Latvijas Vēstnesis, 2010. 